\title{
PENINGKATAN KOMPETENSI GURU KELAS MELALUI MENGEMBANGKAN SILABUS DAN MENYUSUN RPP DENGAN STANDAR PROSES
}

\author{
Ernawati ${ }^{1)}$ \\ ${ }^{1)}$ SD NEGERI 066655 \\ E-mail: Ernawati060916@yahoo.com
}

\begin{abstract}
Belajar mengajar merupakan suatu proses pencipta kondisi belajar dimana guru bertanggung jawab terhadap pendidikan siswanya. Oleh sebab itu guru sebaiknya memiliki tingkat kompetensi yang baik dalam melaksanakan tugasnya sebagai pengajar baik itu kompetensi pedagogik, kompetensi kepribadian, kompetensi sosial, dan kompetensi profesional. Yang termasuk di dalam kompetensi tersebut adalah bagaimana seorang guru mampu menembangkan Silabus dan RPP sesuai dengan standar proses yang telah di tentkan oleh pemerintah melalui peraturan permendikbud Nomor 22 tahun 2016. Dengan adanya kompetensi tersebut diharapkan guru dapat memotivasi siswa untuk belajar lebih baik, sehingga hasil belajar yang diharapkan berupa pencapaian yang memuaskan. Tujuan dari penelitian ini adalah untuk mengetahui bagaimana peningkatan kompetensi guru kelas dalam mengembangkan silabus dan RPP sesuai dengan standar proses. Penelitian ini menggunakan penelitian tindakan (action research) sebanyak 2 siklus, setiap putaran terdiri dari empat tahap yaitu rancangan, kegiatan, dan pengamatan refleksi dan revisi. Sasaran penelitian ini adalah seluruh guru kelas di SD Negeri $066655 \mathrm{Kec}$. Medan sunggal
\end{abstract}

Kata Kunci : Kompetensi Guru, Mengembangkan Silabus, Menyusun RPP 


\section{PENDAHULUAN}

Guru adalah suatu profesi yang sangat mulia, di pundak para guru maju mundur pendidikan itu akan terbaca. Di dalam masyarakat guru dipandang orang yang serba bisa, mumpuni di bidang apa saja, oleh karena itu guru harus mampu menunjukan berfikir cerdas, berkepribadian mulia, budi perkerti luhur, prilaku jujur, dan rasa sosial nyata.Pembelajaran dalam tataran idealnya harus direncanakan, dilaksanakan, dan dinilai oleh seorang guru serta diawasi oleh kepala sekolah. Namun, dalam praktiknya di lapangan hal ini yang tidak begitu diperhatikan oleh guru yang harus memiliki kompetensi pedagogik dan kepala sekolah yang harus memiliki kompetensi supervisor. Mulyasa (2011: 37) menyatakan bahwa, "Tugas guru untuk menjadi guru profesional meliputi, mendidik, mengajar, dan melatih". Mendidik berarti meneruskan dan mengembangkan nilai-nilai hidup. Mengajar berarti meneruskan dan mengembangkan ilmu pengetahuan dan teknologi. Sedangkan melatih berarti mengembangkan keterampilanketerampilan pada siswa.

Mencermati uraian di atas, terlihat betapa besarnya peran guru dalam membantu pertumbuhan dan perkembangan peserta didik. Guru memiliki peran dan fungsi yang sangat penting dalam membentuk kepribadian, akhlak, mentalitas, dan moral anak. Dengan demikian dapat dikatakan tercapainya tujuan pendidikan di sekolah sangat dipengaruhi oleh sikap guru dalam melaksanakan tugas profesinya. Dari hasil observasi yang peneliti lakukan bahwa kegagalan guru untuk membuat peserta didik itu belajar disebabkan karena faktor guru itu sendiri dan pengawasan kepala sekolah terhadap kinerja dari seorang guru yang bersifat instruksi bukan bersifat bimbingan atau bantuan. Sedangkan dari keterangan guru dapat disimpulkan bahwa, guru bingung ketika harus merumuskan RPP karena mata pelajaran yang diajar berbeda dengan latar belakang pendidikannya dan guru biasanya tinggal mengambil atau copy-paste dari internet atau dari teman seprofesi.

Penelitian ini peneliti batasi pada RPP, seorang guru yang kebingungan atau Copy-paste dalam membuat RPP jauh dari RPP sesuai dengan prinsip-prinsip pengembangan RPP K13 menurut Permendikbud No 22 Tahun 2016 yang mengakibatkan nantinya akan berdampak pada kegagalan proses pembelajaran dan menghambat pula peningkatan mutu sekolah itu sendiri, sehingga upaya untuk meningkatkan kompetensi guru dalam menyusun RPP menjadi fokus dalam penelitian ini. Peneliti menemukan kesenjangan antara RPP yang dibuat guru dengan RPP menurut Permendikbud No 22 tahun 2016. Perencanaan pembelajaran dituangkan ke dalam Rencana Pelaksanaan Pembelajaran (RPP) atau beberapa istilah lain seperti desain pembelajaran, skenario pembelajaran. RPP memuat KD, indikator yang akan dicapai, materi yang akan dipelajari, metode pembelajaran, langkah pembelajaran, media pembelajaran, dan sumber belajar serta penilaian.

Peraturan Pemerintah Nomor 19 Tahun 2005 tentang 8 Standar Nasional Pendidikan menyatakan standar proses merupakan salah satu SNP untuk satuan pendidikan dasar dan menengah yang mencakup: 1) Perencanaan proses pembelajaran, 2) Pelaksanaan proses pembelajaran, 3) Penilaian hasil pembelajaran, 4) dan pengawasan proses pembelajaran. Perencanaan pembelajaran meliputi Silabus dan Rencana Pelaksanaan Pembelajaran (RPP). Silabus dan RPP dikembangkan oleh guru pada satuan pendidikan. Guru pada satuan pendidikan berkewajiban menyusun Silabus dan RPP secara lengkap dan sistematis agar pembelajaran berlangsung secara interaktif, inspiratif, menyenangkan, menantang, memotivasi peserta didik untuk berpartisipasi aktif, serta memberikan ruang yang cukup bagi prakarsa, kreativitas, dan kemandirian sesuai dengan bakat, minat dan perkembangan fisik serta psikologis peserta didik. Upaya perwujudan pengembangan silabus menjadi perencanaan pembelajaran yang implementatif memerlukan kemampuan yang komprehensif. Kemampuan itulah yang dapat mengantarkan guru menjadi tenaga yang professional. Guru yang professional harus memiliki 5 (lima) kompetensi yang salah satunya adalah kompetensi penyusunan rencana pembelajaran. Pengawas sekolah sebagai seorang supervisor akan melakukan supervisi klinis terhadap guru dalam dalam mengembangkan silabus dan menyusun RPP dengan standar proses di SD Negeri 066655 Kec. Medan Sunggal ,sehingga dalam pengawasan yang diberikan supervisor ini dapat meningkatkan profesionalitas guru dan meningkatkan pembelajaran melalui pembelajaran efektif sehingga penelitian ini menjadi penting untuk dilakukan karena berupaya meningkatkan kompetensi guru dalam mengembangkan silabus dan menyusun RPP 
dengan standar proses di SD Negeri 066655 Kec. Medan Sunggal.

Masalah-masalah pokok dalam penelitian ini adalah (1) Bagaimana kompetensi awal guru dalam mengembangkan silabus dan menyusun RPP, (2) Bagaimana penerapan standar proses untuk meningkatkan kompetensi guru dalam mengembangkan silabus dan menyusun RPP, (3) Bagaimana peningkatan kompetensi guru Kelas dalam mengembangkan silabus dan menyusun RPP dengan standar proses di SD Negeri 066655 Kec. Medan Sunggal. Penelitian ini bermanfaat untuk meningkatkan kompetensi guru dalam upaya menjabarkan kurikulum atau program pembelajaran sesuai dengan tuntutan dan konteks lokal, sekolah, serta kelas. Hal ini turut memperkuat relevansi pembelajaran bagi kebutuhan peserta didik. Dengan kompetensi menyusun RPP dengan standar proses yang handal diharapkan para guru dapat memenuhi kompetensinya terutama kompetensi pedagogik. Selain itu dari penelitian ini dapat Meningkatkan profesionalisme guru Kelas yang berkaitan kompetensinya sebagai seorang agen pembelajaran di sekolah.

\section{TINJAUAN PUSTAKA}

\section{Kemampuan Guru ( Kompetensi Guru )}

Menurut Guilford (Suryabrata, 2004:163) membagi kemampuan menjadi tiga jenis yaitu:(1) Kemampuan perseptual adalah melalui kemampuan dalam mengadakan persepsi atau pengamatan yang mencakup faktor-faktor kepekaan indera, perhatian, kecepatan persepsi, (2) Kemampuan psikomotor adalah mencakup beberapa faktor kekuatan, kecepatan gerak, ketelitian, keluwesan,(3) Kemampuan intelektualadalah kecenderungan yang menekankan pada kemampuan akal dimana mencakup beberapa faktor ingatan, pengenalan, evaluasi, berfikir.Menurut Kunandar (2007:63) kemampuan dasar profesionalisme guru dalam mendesain pembelajaran secara rinci dapat dijabarkan sebagai berikut: (1) Merumuskan tujuan instruksional seperti; mengkaji kurikulum mata pelajaran, mempelajari ciri-ciri rumusan tujuan instruksional, mempelajari tujuan instruksional mata pelajaran yang bersangkutan, merumuskan tujuan instruksional mata pelajaran bersangkutan. (2) Mengenal dan dapat menggunakan metode mengajar seperti; memilih atau menggunakan macam-macam metode mengajar, (3) Memilih dan menyusun prosedur instruksional yang tepat seperti; mempelajari kriteria pemilihan materi dan prosedur mengajar, menggunakan kriteria pemilihan materi dan prosedur mengajar, merencanakan program pelajaran, dan menyusun satuan pelajaran.

Kemampuan guru dalam proses belajar mengajar meliputi : (1)menggunakan metode pengajaran, (2)menggunakan alat pengajaran, (3)menggunakanmedia pengajaran,

(4)menggunakan bahan pengajaran, (5)mengikutsertakan keterlibatan siswa dalam pengajaran, (6)melaksanakan evaluasi dalam proses belajar mengajar.Kemampuan guru dalam menyusun bahan pelajaran sangat berpengaruh terhdap kegiatan belajar siswa, berarti berpengaruh pula terhadap pencapaian tujuan instruksional. Penetapan atau penentuan materi pengajaran harus didasarkan pada upaya pemenuhan tujuan pengajaran itu, tidak boleh menyimpang dari tujuan pengajaran. Jika sesuatu materi sudah tersimpul dalam perumusan tujuan khusus pengajaran yang baik dan jelas, maka pada umumnya mudah diduga bahwa perhitungan atau pertimbangan penetapan metode atas dasar materi tidak akan jauh berbeda hasilnya dengan dasar pertimbangan tujuan. Penguasaan bahan atau materi merupakan syarat mutlak yang harus dikuasai oleh guru dengan baik, sebelum melakukan proses belajar mengajar.

\section{b. Silabus}

Silabus pada dasarnya merupakan program yang bersifat makro yang harus dijabarkan lagi ke dalam program-program pembelajaran yang lebih rinci, yaitu rencana pelaksanaan pembelajaran (RPP). Silabus merupakan program yang dilaksanakan untuk jangka waktu yang cukup panjang (satu semester), menjadi acuan dalam mengembangkan RPP yang merupakan program untuk jangka waktu yang lebih singkat. Silabus adalah rencana pembelajaran pada suatu danatau kelompok matapelajarantema tertentu yang mencakup standar kompetensi, kompetensi dasar, materi pokokpembelajaran, kegiatan pembelajaran, indikator, penilaian, alokasi waktu, dan sumber/bahan/alat belajar. Silabus merupakan penjabaran standar kompetensi dan kompetensi dasar ke dalam materi pokokpembelajaran, kegiatan pembelajaran, dan indikator pencapaian kompetensi untuk penilaian. 


\section{Rencana Pelaksanaan Pembelajaran (RPP)}

Menurut Peraturan Pemerintah

No.19 tahun 2005 rencana pelaksanaan pembelajaran adalah seperangkat rencana yang menggambarkan proses dan prosedur pengorganisasian kegiatan pembelajaran untuk mencapai satu kompetensi dasar (KD) yang telah ditetapkan dalam standar isi dan dijabarkan di dalam silabus.Menurut Permendiknas No. 41 Tahun 2007, komponen RPP terdiri dari (1) Identitas mata pelajaran, identitas mata pelajaran, meliputi: satuan pendidikan, kelas, semester, program/program keahlian, mata pelajaran atautema pelajaran, jumlah pertemuan, (2) Standar kompetensi, standar kompetensi merupakan kualifikasi kemampuan minimal peserta didik yang menggambarkan penguasaan pengetahuan, sikap, dan keterampilan yang diharapkan dicapai pada setiap kelas dan/atau semester pada suatu mata pelajaran, (3) Kompetensi dasar, kompetensi dasar adalah sejumlah kemampuan yang harus dikuasai peserta didik dalam mata pelajaran tertentu sebagai rujukan penyusunan indikator kompetensi dalam suatu pelajaran, (4) Indikator pencapaian kompetensi, indikator kompetensi adalah perilaku yang dapat diukur dan/atau diobservasi untuk menunjukkan ketercapaian kompetensi dasar tertentu yang menjadi acuan penilaian mata pelajaran.Indikator pencapaian kompetensi dirumuskan dengan menggunakan kata kerja operasional yang dapat diamati dan diukur, yang mencak up pengetahuan, sikap, dan keterampilan, (5)Tujuan pembelajaran, tujuan pembelajaran menggambarkan proses dan hasil belajar yang diharapkan dicapai oleh peserta didik sesuai dengan kompetensi dasar, (6) Materi ajar, materi ajar memuat fakta, konsep, prinsip, dan prosedur yang relevan, dan ditulis dalam bentuk butir-butir sesuai dengan rumusan indikator pencapaian kompetensi, (7) Alokasi waktu, alokasi waktu ditentukan sesuai dengan keperluan untuk pencapaian KD dan beban belajar, (8) Metode pembelajaran, metode pembelajaran digunakan oleh guru untuk mewujudkan suasana belajar dan proses pembelajaran agar peserta didik mencapai kompetensi dasar atau seperangkat indikator yang telah ditetapkan. Pemilihan metode pembelajaran disesuaikan dengan situasi dan kondisi peserta didik, serta karakteristik dari setiap indikator dan kompetensi yang hendak dicapai pada setiap mata pelajaran, (9) Kegiatan pembelajaran dapat diuraikan sebagai berikut (a) Pendahuluan, pendahuluan merupakan kegiatan awal dalam suatu pertemuan pembelajaran yang ditujukan untuk membangkitkan motivasi dan memfokuskan perhatian peserta didik untuk berpartisipasi aktif dalam proses pembelajaran,(b) Kegiatan Inti, kegiatan inti merupakan proses pembelajaran untuk mencapai KD.

\section{METODE PENELITIAN}

Jenis penelitian yang digunakan adalah penelitian yang menggunakan desain Penelitian Tindakan Sekolah (PTS) dengan pendekatan kualitatif. Sugiyono (2009:10) mengemukakan bahwa penelitian kualitatif memandang objek sebagai sesuatu yang dinamis, hasil konstruksi pemikiran, dan interpretasi terhadap gejala yang diamati, serta utuh (holistik) karena setiap aspek dari objek itu mempunyai satu kesatuan yang tidak dapat dipisahkan, jadi realitas itu merupakan konstruksi atau interpretasi dari pemahaman terhadap semua data yang tampak di lapangan. Penelitian ini merupakan suatu rangkaian langkah untuk mengatasi permasalahan yang timbul dalam ruang lingkup sekolah. Mulyasa (2009:9) mengemukakan bahwa penelitian tindakan sekolah (PTS) merupakan upaya untuk meningkatkan kinerja sistem pendidikan dan mengembangkan manajemen sekolah agar menjadi lebih produktif, efektif, dan efisien. PTS dapat diartikan sebagai sebuah upaya untuk memperbaiki kondisi dan memecahkan berbagai persoalan pendidikan yang dihadapi di sekolah. Pengertian tersebut menunjuk pada dua kata yang satu diantaranya harus ada dalam kegiatan penelitian tindakan sekolah, yaitu 
NIAGAWAN Vol 8 No 2 Juli 2019

pemecahan masalah (problem solving) dan peningkatan (improving) kinerja sistem pendidikan serta manajemen sekolah, yang secara keseluruhan akan berdampak pada peningkatan mutu.

Subjek penelitian dalam penelitian ini adalah seluruh guru kelas dari SD Negeri 066655 . jumlah subjek penelitian ini 14 guru . Penelitian ini dilaksanakan Sejak bulan juli 2018 hingga oktober 2018 sehingga dapat dikatakan waktu penelitian ini pada tahun pelajaran 2018/2019. Penelitian ini difokuskan pada kompetensi awal guru dalam mengembangkan silabus dan menyusun RPP menurut Permendikbud No 22 Tahun 2006, penerapan supervisi klinis dalam meningkatkan kompetensi guru dalam menyusun RPP menurut Permendibud No 22 Tahun 2006, dan peningkatan kompetensi guru dalam menyusun RPP menurut Permendiknas No 22 Tahun 2006. Dalam penelitian ini tidak melihat aspek lain selain standar proses yang membuat peningkatan kompetensi guru Kelas dalam mengembangkan silabus dan menyusun RPP.

Instrumen penelitian merupakan alat bantu dalam mengumpulkan data. Dalam penelitian ini yang berorientasi pada proses membuat peneliti berfokus pada proses tindakan yang meliputi perilaku supervisor dan guru, respon dari guru mengenai supervisor dan tindakan yang diberikan, dan suasana proses tindakan sehingga penelitilah yang menjadi instrumen kunci dengan bantuan lembar observasi dan pedoman wawancara. Selain itu untuk menilai kompetensi guru dalam menyusun RPP supervisor memberikan penilaian berpedoman pada APKG (Acuan Penilaian Kompetensi Guru) kemudian supervisor memberikan umpan balik dengan berpedoman pada hasil penilaian menurut APKG dan berdasarkan komponen serta prinsip penyusunan RPP menurut Permendikbud No 22 Tahun 2006, umpan balik dari pengawas sekolah/supervisor ini berguna untuk mengetahui kekurangan dari RPP yang dibuat guru. Catatan lapangan dari dokumentasi (Hasil penilaian \& umpan balik pengawas sekolah/supervisor) dipakai untuk mendeskripsikan kondisi awal kompetensi guru dalam mengembangkan silabus dan menyusun RPP dan peningkatan kompetensi guru dalam mengembangkan silabus dan menyusun RPP, sedangkan catatan lapangan dari observasi, wawancara, dan dokumentasi (foto) digunakan untuk mendeskripsikan penerapan tindakan yang dilakukan meliputi bagaimana perilaku supervisor, perilaku subjek penelitian, dan suasana yang terjadi di kelas saat itu. Teknik analisis data yang digunakan dalam penelitian ini adalah naratif kualitatif yakni mendeskripsikan atau menggambarkan bagaimana kondisi awal kompetensi guru dalam menyusun RPP, pelaksanaan tindakan memberikan supervisi pada guru untuk menyusun RPP yang sesuai dengan Permendikbud No 22 tahun 2006, dan peningkatan yang dialami guru dalam menyusun RPP. Miles \& Huberman (Dalam Sugiyono, 2009:246) mengemukakan bahwa aktivitas dalam analisis data kualitatif dilakukan secara interaktif dan berlangsung secara terus sampai tuntas, sehingga datanya sudah jenuh. Aktivitas dalam analisis data, yaitu reduksi data, penyajian data, dan penarikan kesimpulan. Penelitian ini menggunakan penelitian tindakan (action research) sebanyak 2 siklus, setiap putaran terdiri dari empat tahap yaitu rancangan, kegiatan dan pengamatan, refleksi dan revisi . Sasaran penelitian ini adalah guru kelas di SD Negeri 066655 Dari hasil analisis didapatkan bahwa kompetensi guru dalam menyusun silabus dan RPP sesuai mengalami peningkatan dari siklus I (mengembangkan silabus $40 \%$ dan menyusun RPP 30\% ), menjadi pada siklus II (mengembangkan silabus $80 \%$ dan menyusun RPP 80\%) Sedangkan dari hasil penelitian menunjukkan bahwa kompetensi guru dalam mengembangkan silabus dan RPP sesuai standar proses mengalami peningkatan sehingga berpengaruh terhadap pembelajaran di kelas .Kesimpulan dari penelitian ini adalah dengan kompetensi guru kelas dalam mengembangkan silabus 
dan menyusun RPP sesuai dengan standar proses dapat berpengaruh positif terhadap pembelajaran siswa di SD Negeri 060887 sehingga dapat digunakan sebagai pembelajaran bidang studi yang lain.

Penelitian ini terbagi menjadi dua siklus yakni siklus I \& siklus II. Kegiatan siklus I ini berguna untuk mengetahui kompetensi awal guru dalam mengembangkan dan menyusun RPP menurut Permendikbud No 22 Tahun 2006. Dari hasil penilaian dan umpan balik yang telah diberikan supervisor dapat disimpulkan bahwa terdapat kesenjangan antara RPP yang dibuat guru dan RPP menurut Permendibud No 22 Tahun 2006 terutama dalam perumusan langkah kegiatan inti yang harus berlangsung secara interaktif,inspiratif, menyenangkan, menantang, efisien, memotivasi peserta didik untuk berpartisipasi aktif, serta memberikan ruang ang cukup bagi prakarsa, kreativitas dan kemandirian sesuai dengan bakat, minat dan perkembangan fisik serta psikologis peserta didik. serta konfirmasi dan instrumen penilaian yang belum lengkap. Siklus I terdiri perencanaan, pelaksanaan, observasi, dan refleksi. Dalam kegiatan perencanaan tindakan supervisor membuat kesepakatan waktu dan tempat bersama subjek penelitian untuk berdiskusi tentang mengembangkan silabus, RPP yang telah dibuatnya, menyiapkan rencana pelaksanaan pertemuan, menyiapkan materi yang akan disampaikan, menyiapkan lembar observasi kegiatan, dan menyiapkan pedoman wawancara.

Dalam pelaksanaan tindakan, pada hari sabtu tanggal 16 Juli 2018, subjek penelitian bersepakat untuk berdiskusi tentang RPP yang ideal seperti apa. Pertemuan ini disepakati dimulai pada jam 10.00 di ruangan guru SD Negeri 066655. Dalam observasi tindakan yang dilakukan peneliti berlangsung setelah kegiatan untuk memberikan penilaian terhadap RPP yang dibuat guru dengan berpedoman pada APKG dan memberi umpan balik berdasarkan hasil penilaian serta berdasarkan komponen \&
NIAGAWAN Vol 8 No 2 Juli 2019

prinsip penyusunan RPP menurut Permendikbud No 22 Tahun 2006. Dari hasil penilaian terhadap RPP yang dibuat guru dapat disimpulkan bahwa RPP yang dibuat sudah sesuai dengan Permendikbud no 22 tahun 2006 tetapi ada beberapa komponen yang harus dilengkapi seperti penekanan pada keterkaitan dan keterpaduan antara $\mathrm{KD}$, materi pembelajaran, kegiatan pemebelajaran, indicator pencapaian kompetensi, penilain dan sumber belajar kemudian masih banyak guru yang belum mahir dalam penerapan teknologi sebagai media pemebelajaran di kelas maupun penilaian.kemudian pengawas sebagai supervisor memberikan umpan balik terhadap guru. Dalam kegiatan refleksi, terdapat beberapa kekurangan dalam pelaksanaan tindakan yakni diperlukannya seorang ahli desain pembelajaran untuk memberikan penguatan dalam guru menyusun RPP sehingga dalam kegiatan atau siklus berikutnya dapat diajak untuk berkolaborasi sedangkan kelebihan dari tindakan ini terjadi peningkatan kompetensi guru dalam menyusun RPP terutama yang berkenaan dengan kegiatan inti dan instrumen penilaian. Subjek penelitian merasa mendapat tambahan pengetahuan tentang penyusunan RPP sesuai Permendikbud No 22 Tahun 2006, supervisor menilai kompetensi subjek penelitian dalam menentukan metode pembelajaran yang tepat sesuai dengan situasi dan kondisi siswa masih perlu untuk ditingkatkan, dan supervisor selain memberikan umpan balik secara tertulis perlu kiranya memberikan umpan balik secara lisan.

Siklus II terdiri perencanaan, pelaksanaan, observasi, dan refleksi. Pada kegiatan perencanaan ini beberapa hal yang dilakukan supervisor adalah sebagai berikut: (1) mendorong guru untuk mengemukakan permasalahan yang dialaminya dalam menyusun RPP yakni permasalahan pemilihan metode pembelajaran kemudian membuat solusi bersama subjek penelitian; (2) memberikan umpan balik secara lisan 
untuk member penguatan terhadap solusi dari masalah subjek penelitian (3) membuat kesepakatan waktu dan tempat bersama subjek penelitian untuk berdiskusi tentang RPP yang telah dibuatnya pada hari sabtu tanggal 19 Oktober 2018 jam 12.30 WIB; dan (4) praktik subjek penelitian dalam menyusun RPP dikerjakan secara mandiri di rumah. Pada hari sabtu tanggal 19 Oktober 2018, pengawas pembina bersama subjek penelitian bersepakat untuk berdialog tentang permasalahan yang dialami subjek penelitian saat mengembangkan silabus dan menyusun RPP dengan standar proses, solusi dari permasalahan tersebut, dan pemberian umpan balik secara lisan oleh pengawas pembina. Pertemuan ini disepakati dimulai sekitar jam 12.30 WIB dan ada seorang subjek penelitian. Pertemuan yang bertempat di ruang guru dimulai dengan pengarahan dari pengawas pembina sebagai seorang supervisor untuk membentuk tempat duduk secara melingkar sehingga diskusinya dapat didengar dalam forum. Supervisor kemudian memberikan kesempatan bagi subjek penelitian untuk mengemukakan permasalahan yang dialami saat mengembangkan silabus dan menyusun RPP dengan standar proses untuk dicari solusinya dalam forum UKG.

Pada tahap observasi dapat disimpulkan bahwa supervisor pada siklus II terhadap RPP subjek penelitian dapat disimpulkan bahwa kompetensi guru dalam mengembangkan silabus dan menyusun RPP tergolong tinggi karena subjek penelitian dapat memilih metode yang tepat sesuai situasi dan kondisi siswa dan kelas, kemudian bias menyesuaikan metode dengan minat dan bakat siswa serta sudah memakai teknologi seperti proyektor dan laptop dalam melangsungkan pembelajaran di kelas.Tahap refleksi dilakukan untuk menentukan apakah tindakan siklus II sudah berhasil atau belum. Berdasarkan analisis hasil penilaian RPP yang dibuat subjek penelitian setelah siklus II berakhir menunjukkan taraf peningkatan dalam menentukan metode yang tepat sesuai dengan situasi dan kondisi siswa dan kelas, dan melengkapi instrumen penilaian. Pada siklus II subjek penelitian telah mengungkapkan permasalahan yang dialaminya saat menyusun RPP dan berdialog bersama supervisor tentang solusi dari permasalahan tersebut. Apabila beberapa orang subjek penelitian masih menemui permasalahan dalam menyusun RPP maka akan diberi masukan atau saran mengenai permasalahan tersebut secara mandiri atau bersifat konsultatif.Pengawas pembina yang dilakukan terhadap RPP, ternyata mendapat respon dari guru, guru tersebut mencoba untuk mengimplementasikan dalam pembelajaran dan menularkannya pada guru lain Dari wawancara yang dilakukan pada empat belas guru kelas dapat disimpulkan bahwa guru yang diberi arahan dan bimbingan dari pengawas pembina mencoba untuk mengaplikasikan RPP dalam pelaksanaan pembelajaran dengan menitikberatkan pada siswa yang belajar serta memakai metode yang inovatif, guru yang diberi tindakan memberikan informasi pada guru lain jika guru lain tersebut bertanya, dan guru yang lain sering mempertanyakan bagaimana menentukan metode yang cocok dalam pembelajaran.

\section{HASIL DAN PEMBAHASAN}

Dari hasil analisis didapatkan bahwa kompetensi guru kelas dalam menyusun silabus dan RPP sesuai mengalami peningkatan dari siklus I (mengembangkan silabus $40 \%$ dan menyusun RPP 30\% ), menjadi pada siklus II (mengembangkan silabus $80 \%$ dan menyusun RPP 80\%) Sedangkan dari hasil penelitian menunjukkan bahwa kompetensi guru dalam mengembangkan silabus dan RPP sesuai standar proses mengalami peningkatan sehingga berpengaruh terhadap pembelajaran di kelas. Kompetensi awal guru dalam mengembangkan silabus menyusun RPP diperoleh dari hasil wawancara dan observasi peneliti terhadap RPP subjek penelitian serta penilaian dan 
umpan balik dari Supervisor terhadap RPP subjek penelitian saat praobservasi. Hasil wawancara peneliti terhadap beberapa subjek penelitiandan dapat disimpulkan bahwa guru bingung ketika harus merumuskan RPP karena mata pelajaran yang diajar berbeda dengan latar belakang pendidikannya serta masih menggunakan RPP hasil MGMP yang dirasa belum sesuai dengan Permendiknas No 41 Tahun 2007.

Pada tahap observasi ini supervisor memberikan penilaian terhadap RPP yang dibuat subjek penelitian pada prasiklus, siklus I, dan Siklus II berdasarkan APKG (Alat Penilaian Kompetensi Guru). APKG digunakan sebagai pedoman penilaian RPP dalam penelitian ini karena dalam APKG terdapat berbagai model instrumen yang dapat dipakai dalam penilaian kinerja guru yakni skala penilaian dan (lembar) observasi (Depdiknas, 2008:35). Pada prasiklus supervisor memberikan penilaian terhadap 11 RPP guru yang bersedia menjadi subjek penelitian tetapi pada siklus I \& II supervisor memberikan penilaian terhadap 10 RPP yang dibuat subjek setelah diberi umpan balik karena seorang subjek penelitian tidak mengumpulkan RPP setelah diberi tindakan dengan alasan sibuk karena memliki banyak tugas dari sekolah.Perbedaan latar belakang pendidikan dengan pelajaran yang diajarkan oleh seorang guru tentu menimbulkan permasalahan dalam pembelajaran.Permasalahannya antara lain guru tersebut tidak memahami konsepkonsep kunci dari sebuah mata pelajaran, guru tersebut kesulitan dalam mengimplementasikan kurikulum suatu mata pelajaran pada pembelajaran terutama pada perencanaan pembelajaran yang bermuara pada RPP, dan tidak terlalu menguasai materi pelajarannya. Hasil observasi peneliti terhadap RPP mata pelajaran IPS dapat disimpulkan bahwa terdapat kesenjangan antara RPP yang dibuat guru dengan RPP menurut Permendikbud No 22 tahun 2006. Kesenjangan atau beberapa komponen yang tidak sesuai dengan Permendikbud No 22 tahun 2006 yaitu, pertama, identitas mata pelajaran belum lengkap, dalam RPP tersebut belum mencantumkan satuan pendidikan, kedua, kegiatan pembelajaran yakni dalam kegiatan inti belum disesuaikan dengan bakat dan minat siswa ketiga, penilaian hasil belajar belum lengkap, dalam RPP tersebut belum mencantumkan cara penyekorannya. Hal yang sama peneliti juga jumpai pada RPP mata pelajaran lain yang dalam kegiatan pembelajaran terutama dalam kegiatan inti belum memasukkan media pembelajaran yang kreatif dan inovatif. Ketidaksesuaian RPP buatan guru didukung oleh hasil penilaian dan umpan balik dari supervisor pada praobservasi terhadap RPP dapat disimpulkan bahwa kompetensi guru dalam menyusun RPP tergolong sedang karena belum sesuai dengan permendikbud No 22 tahun 2016 pada kegiatan inti serta instrumen penilaian belum lengkap sedangkan pada RPP mata pelajaran lain juga ditemukan kesenjangan serupa.

Kompetensi awal guru dalam menyusun RPP jika dilihat dari model analisis kategori dari segi kompetensi atau berpikir abstrak, tergolong rendah karena tidak memiliki inisiatif dalam menyusun RPP karena hanya copy-paste dari MGMP sedangkan kompetensi awal guru mata pelajaran lain dalam menyusun RPP jika dilihat dari model analisis kategori dari segi kompetensi atau berpikir abstrak, tergolong rendah karena guru kebingungan dalam merumuskan RPP karena mata pelajaran yang diajarkan berbeda dengan latar belakang pendidikannya dan tidak memiliki inisiatif dalam menyusun RPP karena hanya copy-paste dari MGMP. Kompetensi berpikir abstrak yang rendah ini akan mengakibatkan kinerja guru yang belum maksimal terutama dalam pembelajaran di kelas karena pelaksanaan pembelajaran tidak akan maksimal jika tidak didukung oleh perencanaan pembelajaran yang matang dan perencanaan pembelajaran ini bermuara pada RPP. Pembelajaran yang tidak maksimal merupakan permasalahan dalam 
NIAGAWAN Vol 8 No 2 Juli 2019

satuan pendidikan. Kepala sekolah merupakan pimpinan satuan pendidikan yang bertanggung jawab dalam berjalannya pembelajaran, jika pembelajaran tidak maksimal diperlukan supervisi dari kepala sekolah sebagai seorang supervisor untuk menanggulangi masalah guru dalam menyusun RPP.

Pada tahap pendahuluan, supervisor melakukan kesepakatan dengan subjek penelitian tentang waktu dan tempat supervisi serta pemberian informasi tentang tujuan pelaksanaan supervisi. Kemudian supervisor pada saat pelaksanaan supervisi klinis pada siklus I memberikan informasi yang berkaitan dengan RPP dan pada siklus II bersama subjek penelitian menggali permasalahan yang dialami subjek saat menyusun RPP serta dicari solusinya bersama supervisor. Hal diatas sesuai dengan pendapat dari Burhanuddin, dkk (2007:37) bahwa pada pertemuan pendahuluan atau praobservasi, supervisor membicarakan kompetensi mengajar yang ingin ditingkatkan oleh guru kemudian disepakati bersama oleh guru dan supervisor. Pelaksanaan supervisi klinis pada tahap pendahuluan ini membutuhkan kiat supervisor dalam menciptakan suasana yang menyenangkan, suasana kekeluargaan, kesejawatan, dan kehangatan. Guru tidak merasa takut atau tertekan sehingga guru mau dan berani mengungkapkan permasalahan dan kebutuhan dalam mengajar di kelas.

\section{KESIMPULAN DAN SARAN}

Kesimpulan

Hasil penelitian dan pembahasan menunjukkan bahwa (1) kompetensi awal guru dalam menyusun RPP tergolong rendah karena guru kebingungan dalam merumuskan RPP karena mata pelajaran yang diajarkan berbeda dengan latar belakang yang dimiliki dan tidak memiliki inisiatif dalam menyusun RPP karena hanya copy-paste dari teman sejawat ataupun dari MGMP; (2) penerapan supervisi klinis untuk meningkatkan kompetensi guru dalam menyusun RPP terbagi menjadi dua siklus dalam setiap siklus melalui tiga tahap yakni tahap pendahuluan, observasi, dan umpan balik. Penerapan supervisi klinis ini dapat dikatakan berhasil karena ketiga tahap dalam setiap siklus berjalan lancar; (3) penerapan supervisi klinis dapat meningkatkan kompetensi guru dalam menyusun RPP. Hal ini dapat dilihat dari perubahan ke arah yang lebih baik dari subjek penelitian dalam menyusun RPP.dan tidak memiliki inisiatif dalam menyusun RPP karena hanya copy-paste. Pada prasiklus kompetensi guru dalam menyusun RPP tergolong rendah karena guru kebingungan dalam merumuskan RPP karena mata pelajaran yang diajarkan berbeda dengan latar belakang pendidikannya. Pada siklus I kompetensi guru dalam menyusun RPP tergolong sedang karena subjek penelitian kebingungan dalam memilih metode pembelajaran yang tepat dan pada RPP dalam langkah-langkah pembelajaran belum menekankan pada kegiatan siswa untuk belajar.

Pada siklus II kompetensi guru dalam menyusun RPP tergolong tinggi karena dapat memperbaiki kekurangan RPP sesuai dengan umpan balik supervisor yakni telah berlangsung secara interaktif,inspiratif, menyenangkan, menantang, efisien, memotivasi peserta didik untuk berpartisipasi aktif, serta memberikan ruang ang cukup bagi prakarsa, kreativitas dan kemandirian sesuai dengan bakat, minat dan perkembangan fisik serta psikologis peserta didik. secara lengkap, serta menentukan metode dengan tepat dan dapat memecahkan masalah dalam menyusun RPP dengan berbagai alternatif solusi; dan (4) implikasi pelaksanaan pada pembelajaran di kelas, guru mulai menerapkan pembelajaran inovatif bukan hanya bertumpu pada materi tetapi juga siswa mulai dikenalkan dengan teknologi untuk mengkonstruksikan pengetahuannya sendiri. Dari hasil analisis data didapatkan bukti bahwa kompetensi guru dalam menyusun RPP mengalami peningkatan secara signifikan.

Saran

Sebaiknya guru melakukan penerapan supervisi klinis untuk meningkatkan kompetensi guru, sehingga ketika terjadi perubahan kurikulum guru mampu mengikutinya dengan tanggap,kemudian kepala sekolah sebagai pimpinan harus melakukan supervise secara rutin dan terjadwal agar guru termotivasi 
dan kesalahan pada pembuatan RPP dapat terevaluasi dengan baik.

\section{REFERENSI}

Aqib, Z. 2009. Penelitian Tindakan Sekolah. Bandung: CV Yrama Widya

Burhanuddin., dkk. 2007. Supervisi Pendidikan Dan Pengajaran: Konsep, Pendekatan, dan Penerapan Pembinaan Profesional. Malang: FIP UM

Maisyaroh. 2001. Supervisi Klinis: Salah Satu Pendekatan Dalam Pelaksanaan Supervisi Pengajaran. Malang: FIP UM.

Mulyasa, E. 2009. Penelitian Tindakan Sekolah. Bandung: PT Remaja Rosdakarya

Muslim, SB. 2009. Supervisi Pendidikan Meningkatkan Kualitas Profesionalisme Guru. Bandung: CV Alfabeta.

Kunandar. 2007. Guru Profesional Impelementasi KTSP dan Sukses dalam Sertifikasi Guru. Jakarta: Rajawali Pers.

Suryasubrata.1997. Proses Belajar Mengajar di Sekolah. Jakarta: Rineka Cipta

Mulyasa, E. 2003. Kurikulum Berbasis Kompetensi: Konsep, Karakteristik, dan Implementasi. Bandung: PT Remaja Rosdakarya

----------, 2012. Penelitian Tindakan Sekolah. Bandung: PT Remaja Rosdakarya

----------, 2013. Pengembangan dan Implementasi Kurikulum 2013. Bandung: PT Remaja Rosdakarya

Harahap, Baharuddin. 1983. Supervisi Pendidikan yang Dilaksanakan oleh Guru, Kepala Sekolah, Penilik dan Pengawas Sekolah. Jakarta:

DamaiJaya 